\title{
A BÜROKRATIKUS ÉS CENTRALIZÁLT FRANCIAORSZÁGI IRÁNYÍTÁSI MODELLT MÓDOSÍTÓ VÁLTOZÁSOK
}

\author{
BAJOMI IVÁN \\ ELTE TáTK
}

Tanulmányom elején a napóleoni centralizált oktatásirányítás kezdeteit és főbb jellemzőit mutatom be. Ezután négy olyan fejleményről szólok, melyek nyomán némiképp módosult a franciaországi centralizált és bürokratikus oktatásirányítási modell. Először arról írok, hogy a 19. század végén miként kapcsolódhattak be a tanárok képviselői az oktatásirányító szervek müködésébe. Majd azt mutatom be, hogy a franciaországi oktatásirányítás terén a 20. század nyolcvanas éveiben lezajlott kismértékü decentralizációs folyamatok keretében hogyan jöttek létre sokszereplős oktatásügyi együttmüködések a kiemelt oktatási körzetekben. Szólok még a hagyományos oktatásirányítási modellt némiképp módosító újfajta értékelési mechanizmusok kiépüléséről. Ezután a bürokratikus irányítási logika érvényesülését nehezítő szülői és intézményi stratégiákról szólók. Végül azt érzékeltetem, hogy a bemutatott öt különböző logika, illetve szabályozási mechanizmus hibridizált formában jut érvényre a francia oktatásügyben.

Kulcsszavak: Napóleon centralizált modellje, tanárszervezetek részvétele, sokszereplős együttmüködések, vitatott értékelési mechanizmusok, szabályozás kontra iskolapiac

As opening of my study I present the beginnings and main features of the centralised educational model of Napoleon. Then, I mention four developments that have led to some changes of this model. Firstly, at the end of the 19th century, teachers' representatives could become involved in the work of the bureaucratic governing educational institutions. Secondly, in the 1980's a small-scale decentralisation led to the development of a multi-stakeholder educational co-operation within educational priority aeras. Thirdly, I note the newly developed evaluation methods that somewhat altered the traditional school-administration model. Fourthly, I refer to those strategies of parents and schools that undermine the prevailing bureaucratic regulation. Finally, I demonstrate that the five different logic and regulatory models presented in my study coexist in the French educational system in a hybrid form.

Keywords: the centralized model of Napoleon, participation of teachers' organizations, co-operation between multiple actors, disputed evaluation tools, regulation vs school market

Levelező szerző: Bajomi Iván, 1118 Budapest, Tűzkő utca 1. VI. 19. E-mail: ibajomi@freemail.hu 

anulmányomban a centralizált és bürokratikus oktatásirányítás egyik mintaképének tekintett francia modell egyes sajátosságait és e rendszer módosulásait szeretném bemutatni. Munkám során egyrészt francia szerzők kutatásaira fogok támaszkodni, másrészt a Reguleducnetwork betűszóval jelölt, Franciaország mellett további négy európai országra (Anglia, Belgium Franciaajkú Közössége, Magyarország és Portugália) kiterjedt nemzetközi kutatás eredményeire, amelynek munkálataiban jómagam hazai kutatásvezetőként vehettem részt.

\section{A középfokú és a felsőfokú oktatást egybefogó Császári Egyetem}

A centralizált modell előzményei elsősorban az I. Napóleon idején létrehozott Császári Egyetemre vezethetők vissza. Minthogy egy korábbi tanulmányomban már felvázoltam a Bonaparte nevéhez köthető francia tanügyirányítási rendszer fő jellemzőit (Bajomi 2013), Karády Viktor pedig egy kiváló könyvben részletesen is bemutatta ennek létrejöttét (Karády 2005), most dióhéjban foglalom össze e rendszer fö sajátosságait.

Egy olyan bürokratikus rendszert hoztak létre, amely a szintén Napóleon által 1800ban kiépített közigazgatási rendszertől elkülönülten működik. Első látásra meglepőnek tünhet, hogy a Császári Egyetem névvel illették azt a rendszert, amely a középfokú oktatást is magában foglalta. Ezt az magyarázza, hogy a Franciaországot diktatórikusan irányító Bonaparte az elit új nemzedékeinek nemzeti, illetve a császárhü szellemben való nevelése érdekében fontosnak tartotta, hogy a magasabb szintű oktatási intézmények, azaz az egyetemi fakultások és az ezekre felkészítő líceumok irányítása egy kézben legyen. Ennek megfelelően az oktatást irányító Nagymester hatásköre egyaránt kiterjedt a középiskolákra és az egyetemekre. Az oktatás e két szintje közötti szoros kapcsolat egyébként abban is kifejeződik, hogy a francia érettségi vizsga mindmáig a felsőfokú képzés első, egyetemi beiratkozásra is feljogosító diplomájának számít.

A közigazgatás és az oktatásirányítás elkülönültsége területi szinten is megjelenik. Míg a közigazgatás alapvető területi egységét Napóleon óta a közelmúlt regionális reformjaiig a közel száz megye alkotta, területi oktatásirányító szervből jóval kevesebb volt. Minthogy a táblabíróságok székhelyén helyezték el ezeket, számuk még a húszat sem érte el. Területük viszont általában jóval nagyobb volt a megyékénél, ráadásul a kétféle területi egység nem is fedte le egymást. Az académies névvel illetett tankerületek élére rektorokat (recteurs) neveztek ki. A fentiek miatt a rektor hatáskörébe nemcsak az egyetemi fakultások, hanem az érettségit adó iskolák irányítása is beletartozott. Ugyanakkor a 19. században jó ideig az alapfokú oktatást illetően szinte semmilyen hatáskörük nem volt a rektoroknak. Az 1848-as forradalom után az elemi iskolák a megyéket vezető állami megbízottak, a prefektusok irányítása alá kerültek, így például 1850-ben az ő hatáskörükbe került a községi tanítók visszahívása, illetve felfüggesztése. Ma már viszont a tankerületek hatásköre az oktatási rendszer minden szintjére kiterjed.

A tankerületi irányításra a politikai típusú vezérlés és bürokratikus szabályozás egyfajta kevert mintája volt jellemző. Az Amiens-ben ténykedett rektorok müködését bemutató írásból kiderül, hogy munkájuk kezdetben egyedi döntésekből, minisztériumi körlevelek továbbításából, tankerületi tanácsülések megszervezéséből, továbbá a legálisan és feketén müködő iskolák felkereséséből állt (Poucet 2008). Ezenkívül új iskolák megszervezésén is dolgoztak, miként azon is, hogy a líceumokhoz kapcsolódóan újjászer- 
vezzék helyi szinten az egyetemi oktatást, melynek kereteit felszámolták a forradalom idején. Az oktatási miniszter által kinevezett rektoroktól annak elősegítését is elvárták, hogy a tanszemélyzet tagjai, pl. a községi tanítók lojálisak legyenek az adott politikai rendszerhez. ${ }^{1}$

\section{Részvételi mechanizmusokkal kiegészített centralizált irányítási rendszer}

A tanszemélyzet politikai lojalitásának fegyelmi eljárások és elbocsátások révén történő kikényszerítéséhez képest a Párizsi Kommünre következő III. Köztársaság időszaka hozott némi változást. Ekkoriban a győztes polgári erők - köztük a korszak neves tárcavezetője, Jules Ferry - kiemelt célnak tekintették az oktatás terén korábban erőteljesen érvényesült egyházi befolyás visszaszorítását. E cél jegyében elő kívánták segíteni, hogy a tanárok komoly szerepet vállaljanak egy új, világi alapon álló erkölcs elterjesztésében. Paradox módon ennek a kifejezetten politikai jellegű célnak az eléréséhez olyan diskurzust alakítottak ki, amelyben központi szerepet kapott a tanügyben dolgozók politikamentességének és önigazgatásának gondolata. A központi szintü tanügyi tanács (Conseil supérieur de l'instruction publique - Közoktatási Főtanács) átszervezése idején mondott egyik beszédében Ferry a „self government' (önkormányzat) angol kifejezéssel élt ${ }^{2}$ (Bongrand 2012). A miniszter és munkatársai arra jutottak, hogy a tanárok státuszát oly módon kell átalakítani, hogy az állam és az önkormányzatok alkalmazásában álló tanszemélyzet függetlenedjen a napi politikától, ugyanakkor némi befolyásra tegyen szert a mind nagyobbra növekvő tanügyirányítási gépezet működtetésében.

E cél elérésének egyik eszközeként a Császári Egyetem idején létrehozott és utóbb több ízben átformált Főtanácsot úgy szervezték át, hogy míg korábban több egyház is képviseltette magát a grémiumban, az 1880-ban újjászervezett testületben egyházi részről csupán a teológiai karok, valamint a magániskolák névvel illetett egyházi oktatási intézmények képviseltethették magukat - igen szerény mértékben. Ugyanakkor jelentős számban kerülhettek be a tanácsba olyan személyek, akik a különböző nagy presztízsü szakföiskolákat (grandes écoles) képviselték, illetve akiket az állami oktatási intézményekben dolgozó tanárok különböző, „,karok” névvel illetett csoportjai delegáltak választások útján. (Míg a középiskolai tanárok a tankerületi szintű tanácsokban jutottak képviselethez, az elemi iskolák tanárai a tankerületek megyei szintủ tanácsaiba küldhettek képviselőket a 19. század utolsó évtizedeiben.)

Érdekes módon a francia neveléstörténészek máig nem készítettek átfogó elemzést az egészen a második világháborúig fennállt, majd más néven újjászervezett Főtanács működéséről. Más forrás híján Jean Zay-nek, az 1936-ban alakult Népfrontkormány egykori oktatási miniszterének a Pétain-rendszer börtönében papírra vetett szavaiból kaphatunk némi képet e testület működéséről. „Bizonyos minisztériumi tervezeteket kötelező volt a Főtanáccsal véleményeztetni, más esetekben ez fakultatív volt. Mindenesetre a miniszternek jogában állt figyelmen kívül hagynia az ellenvéleményeket. Nem nehéz kitalálni,

\footnotetext{
Míg kezdetben kevés embert foglalkoztattak a tankerületek és az ezek alá tartozó megyei tanfelügyelöségek, napjainkra ezek már nagy létszámú hivatalok.

2 Akkoriban még nem létezett a francia nyelvben az „autogestion” szó, amit magyarra az „önigazgatás” kifejezéssel lehet visszaadni.
} 
hogy amikor így járt el, nagy izgalmat váltott ki a tanügyben dolgozók körében." (Zay é. n. $)^{3}$

A rendszerszintű reformokról és a tantervekről tárgyaló Főtanács mellett már 1873ban létrejött egy olyan testület, amely a tanárok kinevezésével és előmenetelével foglalkozott. E kérdésnek igen nagy jelentőséget tulajdonítottak a tanárok, mivel sok esetben a protekció alapján dőlt el, hogy kiket léptetnek elő soron kívül, illetve neveznek ki valamelyik nagyobb presztízsü, illetve jó helyen lévő iskolába. Charles Georgin jogász 1911-es disszertációjának alábbi mondata jól mutatja, hogy a tanárszervezetek megszaporodásában, és ezen belül is az első középiskolai tanárokat tömörítő országos egyesület ${ }^{4}$ létrejöttében igen fontos szerepet játszottak ezek a kérdések. „Ez a nagy felbuzdulás vélhetően [...] az előléptetések kérdésére vezethető vissza: ha nem ily rosszul szabályozták volna az előléptetéseket, vagy pontosabban szólva szabályozták volna ezt a kérdést, nem indultak volna olyan nagy fejlődésnek a közalkalmazottakat tömörítő egyesületek." (Verneuil 2016: 66.)

A tanárok elhelyezésével és kinevezésével foglalkozó minisztériumi tanácsok utóbb paritásos testületekké alakultak. Nagy változást jelentett összetételük tekintetében, hogy míg eleinte a miniszter nevezte ki az új tagokat, az 1924-ben létrejött balközép „baloldali kartell” kormányzása idején lehetővé vált, hogy szakszervezeteket alakítsanak a közalkalmazottak, és egyben arra is mód nyílt, hogy az oktatásügy paritásos bizottságába az egyesületekből szakszervezetekké alakult érdekvédelmi szervek küldjenek tagokat. A paritásos tárgyalások során elfogadott szabályok révén sikerült visszaszorítani az előléptetések és kinevezések terén az önkényességet. Vagyis érdekes módon a 19. század végén képviseleti alapra helyezett részvételi mechanizmusok segítették elő azt, hogy nagyobb szerephez jussanak a bürokratikus eljárási szabályok. Egyébként a paritásos testületek munkájába való bekapcsolódás növelte az érdekvédelmi szervezetek súlyát. Ez utóbbiak megerősödésében a tanárok ama megfontolása is szerepet játszhatott, hogy amennyiben nem csatlakoznak valamelyik szakszervezethez, hátrányba kerülhetnek az előléptetésekkel, illetve áthelyezésekkel kapcsolatos, a francia oktatásügyben erősen központosított, országos szintü döntések során.

A Közoktatási Főtanácsba és a paritásos bizottságokba delegált tanároknak, majd később az e grémiumokba bekerült szakszervezeti vezetőknek köszönhetően a tanári szakma delegáltjai még kihirdetésük előtt értesülhettek a tervezett minisztériumi intézkedésekről, sőt kísérletet tehettek ezek befolyásolására, ami persze nem feltétlenül hozott eredményt. A delegáltaknak az országos és alsóbb szintü testületek munkájában való részvétele azt is elősegítette, hogy az érdekképviseletek szakszerübb, megalapozottabb követeléseket fogalmazzanak meg különböző aláírásgyüjtések, demonstrációk, sztrájkok stb. megszervezésekor.

A francia oktatásirányítás főbb vonásairól, illetve ennek az 1808-at követő mintegy másfél évszázadban bekövetkezett változásairól fentebb adott vázlatos kép jól megfelel annak a leírásnak, amelyben Christian Maroy belga szociológus a nemzetállamokat irányító elitek által kialakított oktatási rendszerek szabályozási rendszereinek korai közös sajátosságait emelte ki. „Az oktatással kapcsolatos feladatok komplexitása miatt [az irá-

E két mondatot, valamint minden további, e tanulmányban idézett francia nyelven íródott szövegrészt a szerző fordította.

4 Fédération nationale des professeurs de lycée et du personnel de l'enseignement secondaire féminin (A gimnáziumi tanárok és a középfokú leánynevelőkben dolgozók országos szövetsége). 
nyítási rendszer] bürokratikus jegyeivel mindig együtt járt a tanárok egyéni és kollektív autonómiája, amely ez utóbbiak gyakorlati tapasztalatain és szaktudásán alapult. Ennek köszönhetően a tanárok jelentős mozgástérre tettek szert a tekintetben, hogy miként végzik munkájukat, és ez nagyban megkönnyítette számukra a tevékenységük során fellépő »bizonytalansági tényezők kezelését. Egyúttal szakmai, illetve szakszervezeti vezetőik révén jelentős mértékben bekapcsolódhattak karrierjük irányításába, továbbá egy szakmai elitcsoport (a tanfelügyelői kar) közvetítésével a tantervek alakításába és a pedagógiai módszerek megválasztásába is bevonódtak. [... Ez az irányításmód kétféle szabályozás, az állami, bürokratikus, illetve adminisztratív szabályozás és a szakmai, korporatív, pedagógiai szabályozás - esetenként feszültségekkel teli - társbérleti együttlakásaként [... írható le." (Maroy 2006: 46-47.)5 Itt érdemes megemlíteni, hogy a szerző az iskolák, illetve iskolarendszerek szintjén egyaránt érvényre jutó kettős irányításmód megragadásakor a Chicagói Egyetem 2016-ban elhunyt szociológusának, Charles E. Bidwellnek az iskolai szervezetek és az oktatási rendszerek főként szervezetszociológiai szempontokat mozgósító finom elemzésére támaszkodott (Bidwell 1965).

A tanárszakszervezeteknek a döntésfolyamatokban való részvételét egyes elemzők élesen bírálják. Érdekesen írt a szóban forgó korporatív rendről 2007-ben Hervé Hamon író, újságíró, aki húsz évvel korábban nagysikerű riportkönyvet adott közre egy szerzőtársával a francia tanártársadalomról (Hamon-Rotman 1984): „Az e rend mögött meghúzódó uralkodó elképzelés a következő két előfeltevésen nyugszik. Egyfelől azon, hogy a közalkalmazottak felcserélhetők. Bárki helyettesíteni tud bárkit. Ez egy szép alapelv, csak az baj az vele, hogy korántsem felel meg a valóságnak. Egy ízben a créteil-i tankerület rektora - e posztot akkoriban a baloldalhoz kötődő Christian Forestier töltötte be - azt javasolta pályakezdő tanároknak, hogy nehéz körülmények között müködő alsó középiskolákba menjenek tanítani önkéntesként. Ehhez megfelelő képzést kaptak volna, ráadásul egy speciális kinevezési eljárás révén más, hozzájuk közel álló személyekkel, barátaikkal együtt helyezkedhettek volna el, és megfelelő pedagógiai és vezetői segítséget is nyújtottak volna a számukra. A szakszervezetek erre azonnal kiásták a csatabárdot azt hangoztatva, hogy ezek a személyre szabott állások egy új logika előfutárai lennének. [...] A kettes számú alapelv az, hogy az oktatási rendszer közalkalmazottait nem lehet értékelésnek alávetni. [...] Már-már karikatúraszerü illusztrációja e problémakörnek az intézményvezető által a tanárnak adott érdemjegy, amit utóbb a paritásos bizottsági ülésen addig csiszolnak, amíg az pontosan megfelel az illetőnek az előléptetési rend szerint következő fokozatának." (Hamon 2007: 67-68.)

\section{A centralizációs logikát megtörő 1981 utáni decentralizációs intézkedések}

A Szocialista Pártot vezető Mitterrand 1981-es elnökké választása után megfigyelhető az egységesítő és centralizációs logikát képviselő franciaországi oktatásirányítási hagyományok részleges megkérdőjeleződése. ${ }^{6}$ Ekkoriban jelentős közigazgatási és oktatásügyi decentralizációs folyamatok kezdődtek. Míg az óvodák és elemi iskolák létesítése, fenntar-

5 Christian Maroy-nak, a belgiumi Louvain-la-Neuve-i Egyetem oktatáskutatójának a Reguleducnetwork betűszóval jelölt, öt európai országban végzett oktatásirányítással kapcsolatos vizsgálódások eredményeit szintetizáló írásából származik a fenti idézet.

6 E változásokról részletesebben szóltam egy korábbi tanulmányomban: Bajomi 2013. 
tása korábban is községi hatáskör volt, az alsó és felső középiskolák hálózatfenntartási és -fejlesztési kérdései és az iskolai szabadidős programok kialakítása terén nagyobb szerephez jutottak a megyei és regionális önkormányzatok. Az 1982-1985 között hozott intézkedések nyomán az állami tulajdonban lévő iskolák státusza megváltozott, ettől fogva helyi közoktatási intézménynek (établissement public local d’enseignement - EPLE) nevezik ezeket. Irányító tanács vezeti ezeket az intézményeket, amelyeknek intézményfejlesztési tervet (projet d'établissement) kell kidolgozniuk. ${ }^{7}$ A decentralizálás azonban igen szűk körű volt, lévén, hogy a pedagógiai kérdések, vagyis a tantervi ügyek és a pedagógusok foglalkoztatása állami hatáskörben maradt. Ugyanakkor az épületek és felszerelések fenntartása a területi önkormányzatok hatáskörébe került, és arra is lehetőség nyílt, hogy ez utóbbiak szabadidős iskolai foglalkozások megtartását kezdeményezzék, illetve finanszírozzák.

\section{Az újszerü müködési elveknek teret engedő kiemelt oktatási körzetek}

A hagyományos alá- és fölérendeltségen alapuló bürokratikus irányítási logika meghaladásának irányába mutatott az is, hogy 1981-től az angliai kiemelt oktatási körzetek (Educational Priority Aera) mintájára létrehoztak Franciaország rosszabb szociális jellemzőkkel rendelkező területein számos ZEP-betüszóval jelölt (zones d’éducation prioritaire) elsőbbséget élvező oktatási körzetet, amelyek többlettámogatásban részesültek. Bár a politikai irányváltások nyomán időről időre csökken az e körzetekre jutó figyelem és támogatás, az elmúlt évtizedekben többször hoztak olyan intézkedéseket, amelyek a kiemelt körzetek rendszerének továbbfejlesztésére irányultak.

A ZEP-ek különböző aktorok, intézmények közötti horizontális együttmüködésnek adnak teret. A kiemelt körzetek müködését elemző kutatások igazolták, hogy e körzetekben nemcsak az egyes tantestületek addig egymástól elszigetelt módon dolgozó pedagógusai, illetve a tanárok és az intézményvezetők között alakult ki együttműködés. Megfigyelték azt is, hogy a különböző szolgáltató intézmények (óvodák, iskolák, szociális, egészségügyi és közművelődési intézmények), továbbá civil szervezetek között jön létre szorosabb vagy lazább partnerkapcsolat, például annak érdekében, hogy zökkenőmentes legyen a gyermekek számára a különböző oktatási intézmények közötti átlépés, vagy azért, hogy az iskola környékén élő bevándorolt népesség kultúrájának egyes elemei

\footnotetext{
E tervek olyan rendszeresen megújított komplex dokumentumok, amelyek egyfelől az iskola adottságait veszik számba, másfelől különböző területeken fogalmaznak mg fejlesztési célokat. Az ilyen dokumentumok egyben megjelölik a célok elérését elősegíteni hivatott eszközöket, az egyes részterületek felelőseit, az együttmüködő partnereket, illetve azokat az indikátorokat, amelyek lehetővé teszik az elért eredmények értékelését, netán számszerűsítését. Mint ez a belga határhoz közel fekvő Revin nevű kisvárosban müködő, George Sand írónőről elnevezett alsó középiskola tervéből is kitűnik (Projet d'établissement 2014), az ilyen dokumentumok több részterületre is kitérnek (pl. a hátrányos helyzetű tanulók integrálása, a diákok pályaválasztási terveinek előkészítése, a számítástechnikai ismeretek és a nyelvtudás fejlesztése, az iskola befogadó jellegét erősítő változtatások). A fejlesztési tervek kidolgozásába, rendszeres továbbfejlesztésébe az iskolavezetésen túl a tanárok, az oktatási intézmény egészségügyi dolgozói, ill. szociális munkásai stb. is bekapcsolódnak. A tervekben az is tükröződik, hogy miként működnek közre a célok megvalósulásában helyi egyesületek, illetve a városi, megyei önkormányzatok. Az oktatási intézmények önállóan, ugyanakkor a tankerületi szervekkel együttműködve dolgozzák ki terveiket, amelyek az óraszámok tekintetében nem térhetnek el az országos tantervben rögzítettektől. Kivételt e tekintetben az jelenthet, ha egy iskolában európai szekciónak nevezett, emelt óraszámú nyelvoktatás folyik, vagy sporttagozat müködik.
} 
megjelenhessenek az iskolai ünnepségeken stb. Változást jelentett az is, hogy sok helyütt az együttmüködő intézmények müködésmódját mind jobban meghatározták a közösen kidolgozott helyzetfelmérések és helyi fejlesztési stratégiák (Bajomi 2006a; ChambonProux 1988).

A kiemelt körzetek kapcsán érdemes arról is szólni, hogy a kilencvenes években készült egy olyan értékelés, amely azt mérte fel, hogy mely ZEP-ek érnek el jó eredményeket tanulmányi sikeresség terén (Moisan-Simon 1997). A hozzáadott érték elve alapján végzett, mennyiségi és minőségi jellemzőket egyaránt felhasználó elemzés annak feltárására irányult, hogy a hasonló társadalmi jellemzőkkel leírható ZEP-körzetek közül melyek diákjai érnek el jobb eredményeket az alsó középiskolák kezdő tanévében megtartott országos eredményességvizsgálaton. Többek között az derült ki, hogy a nagy tanulólétszámú körzetekben általában rosszabbak az eredmények. Ugyancsak elemezték azt, hogy miként müködnek a ZEP-körzeteket vezető, az együttmüködő szervezetek képviselőiből és egy főállású koordinátorból irányító tanácsok.

\section{$\mathrm{A} z$ értékelések előtérbe kerülése}

Az imént írottak jól illusztrálják azt, hogy a 20. század utolsó évtizedeiben - részben nemzetközi hatásokra visszavezethetően - Franciaországban is előtérbe került az oktatási folyamatok hatékonyságának értékelése. Ezt az is jelzi, hogy 1987-ben az oktatási tárca statisztikai részlege értékelési és előrejelzési főosztállyá (direction de l'évaluation et de la prospective - DEP) alakult, és a 90-es években már 220 föt alkalmazott. A föosztályt akkoriban vezető, szociológusnak is kiváló Claude Thélot megfogalmazása szerint e részleg missziója az, hogy tükröt tartson az oktatás szereplöi elé az oktatási rendszer müködéséről.

A korábban elkezdődött fejlesztések nyomán a kilencvenes évek elején intézményesültek az elemi iskolák harmadik osztályába lépő és az alsó középiskolai tanulmányaikat elkezdő, 7, illetve 11 éves tanulók körében elvégzett, a matematika, illetve francia órákon szerzett tudást és készségeket felmérni hivatott vizsgálatok. Az országos értékelések történetéről készült egy tanulmány, amelyből megtudható, hogy a minisztériumi értékelési főosztálynak a kezdeményezéseire adott tanárszakszervezeti válaszok hatására csak diagnosztikai jellegü, azaz a tanévkezdéskor elvégzett és a tanári fejlesztőmunkát segíteni hivatott mérések épültek be az oktatás gyakorlatába (Pons 2012). ${ }^{8}$ (Az érdekvédők fellépése ugyanis ellehetetlenítette a tanév végi mérések bevezetését, amelyeket fel lehetett volna használni a tanári munka hatékonyságának értékeléséhez.)

Az értékelési főosztály közgazdász végzettségü munkatársa, Denis Meuret, az Egyesült Államokban, Kanadában és Belgiumban szerzett tapasztalatai alapján kezdeményezte, hogy készüljenek olyan „mérlegek”, amelyek alapján képet lehet alkotni arról, hogy miként alakulnak az oktatási folyamatok az egyes térségek, illetve a francia állam szintjén. Olyan értékelések létrejöttét szorgalmazta, amelyek révén nemcsak az oktatásirányító szervek kaphattak volna képet az oktatási folyamatokról, hanem a társadalmi partnerek is (pl. a szülői szervezetek stb.). Az immár 28 éve rendszeresen elkészített, és $A z$ iskolaügy állapota (L'état de l'école) címü, évente megjelentetett értékelések

\footnotetext{
Pons egyébként arról ír tanulmányában, hogy egy felmérés tanúsága szerint a megkérdezett tanárok mint-
} egy fele tartotta hasznosnak a szóban forgó mérést. 
rendszerének kidolgozásakor többek között a korábban kialakított „eredménytáblák” (tableau de bord) adtak támpontokat. A minisztériumi égisz alatt készült országos szintű mérlegek kapcsán Pons felhívta a figyelmet arra, hogy esetenként az egyes miniszterek aktuális céljai is szerepet játszottak abban, hogy milyen indikátorokat vettek figyelembe. (Például amikor Claude Allègre fel kívánt lépni a tanárok körében tapasztalható tömeges hiányzások ellen, erre vonatkozó jelzőszám is bekerült a kötetbe. Pons arról is ír, hogy „a kiadvány struktúráját egyre inkább a minisztérium igazgatási szempontjai határozzák meg" (Pons 2012: 24).

Ez utóbbi észrevétel átvezet az értékelő tevékenységek függetlenségének kérdéséhez. Egy írásomban (Bajomi 2015) már hírt adtam arról, hogy François Hollande elnöksége idején 2013-2014-ben Natalie Mons oktatáskutató kezdeményezésére létrejött az "Oktatási rendszer értékelésének országos tanácsa” - (Conseil national de l'évaluation du système scolaire - CNESCO). Az oktatási tárcától viszonylag függetlenül müködő, az iskolaügyben érvényre jutó különböző részpolitikák értékelésére vállalkozó szervezetnek az égisze alatt lehetőség nyílt számos, oktatással kapcsolatos probléma sokoldalú elemzésére és megvitatására. Így például e szervezet, amelynek müködésében több kutató mellett a nemzetgyülés néhány képviselője, valamint más szervezetek delegáltjai is részt vesznek, felvette napirendjére a Franciaországban hagyományosan nagymérvü, bár csökkenő mértékű évismétlések problémakörét. Először az idevágó elemzések eredményeinek szintetizálására vállalkoztak, majd az oktatásban érintett érdekcsoportok képviselőinek bevonását lehetővé tevő tematikus vitákat szerveztek, és végül egy reprezentatív összetételünek mondott zsürit alkottak, amely az évismétlések visszaszorítását célzó ajánlásokat fogalmazott meg 2015 elején.

Bár nem jelentek meg olyan értékelések, amelyek kritikát fogalmaztak volna meg a CNESCO müködésével kapcsolatban, a társadalmi párbeszédet elnöksége első két évében zárójelbe helyező Emmanuel Macron oktatási minisztere, Michel Blanquer tervbe vette e szervezet megszüntetését. Egy oktatási kérdésekre szakosodott újságírónő így írt az új miniszter lépéseiről: „Tudományos tekintetben a független értékelés müködik jól, ezért bízhatunk meg a nemzetközi értékelésekben. Miközben ezeket a sorokat írom, éppen egy viszonylagos önállóságot élvező értékelő szervezet, a CNESCO megszüntetésén dolgoznak, hogy ennek a helyébe egy új Iskolaértékelési Tanácsot (Conseil d'évaluation de l'école - CEE) állítsanak, amelyben minisztériumi tisztségviselők is helyet kapnak, és amelynek nem tartozik bele a feladatkörébe az oktatáspolitikák értékelése." (Tourret 2018.) A CNESCO megszüntetésére irányuló tervek oly erős tiltakozást váltottak ki, hogy végül egy felnőttképzési központ egyik tanszékeként működhet tovább a szervezet - ámbár egyes tanárszakszervezetek aggódnak amiatt, hogy a korábbinál kevesebb erőforrásra kell majd támaszkodnia.

Mint láthattuk, más fejlett országokhoz hasonlóan Franciaországban is előtérbe került az oktatási folyamatok értékelésének kérdése, ami a már idézett belga oktatáskutató, Maroy szerint az oktatásirányítás posztbürokratikus irányba történt elmozdulásának egyik jele. Ugyanakkor Franciaországban az oktatási rendszer több szereplője is elutasítóan vagy ambivalens módon viszonyul ahhoz, hogy az értékelés komolyabb

9 Az eredménytáblák eredetileg sok indikátort magukban foglaló, intézményi szintű dokumentumok voltak, amelyeket az iskolák működésmódjának hatékonyságát növelendő, illetve az intézmények önreflexióját elősegítendő alakítottak ki. 
szerepet játsszon az oktatásirányítás terén. Agnès van Zanten neves oktatásszociológus, a Reguleducnetwork-kutatás egyik francia kutatócsoportjának vezetője így ír erről: „A már említett problémák nemcsak az új menedzsmenteszközök bevezetését nehezítik meg, hanem azt is, hogy áttérjenek az előzetes (a priori) egyezségeken, szabályokon és értékeken alapuló szabályozásról az utólagos (a posteriori) szabályozásra, amely az értékelésen, vagy még általánosabban véve, ismereteken alapul. A szakszervezetek igencsak ellenzik ezt, részint azért, mert magukévá tették tagjaik erős fenntartásait, részint azért, mert attól tartanak, hogy csökkeni fog a hatalmuk, lévén hogy az előbbi az erőviszonyokon alapul és azon, hogy el tudnak-e fogadtatni valamifajta, a tanári munkáról és identitásról szóló víziót. A központi és a helyi szintű irányítószerveknek pedig olyan legitimációs és koordinációs problémákkal kell megküzdeniük, amelyek miatt nehezen tudnának vállalkozni az eredményesség olyan, átfogó értékelésére, amely lehetővé tenné, hogy utóbb erre támaszkodva változtassák meg a központi szintű müködésmódokat és a helyi szintű szervezeti és pedagógiai kereteket." (van Zanten 2008: 76-77.)

\section{Az oktatási piac szabályozó szerepe}

Az oktatásirányítás mozgásterét nagyban meghatározzák az oktatási rendszer jellemzői. Így például az, hogy Franciaországban sok magániskola működik. Ezek oroszlánrésze felekezeti jellegű, túlnyomó részt katolikus iskola, amelyek 1959 óta komoly állami támogatást élveznek. Bár jelentősek a regionális eltérések, országos szinten körülbelül 20\%-ra tehető a magániskolák aránya. Ugyanakkor „a családok szintjén nézve a dolgot, majdnem minden második családról elmondható, hogy legalább egyik gyermekük valamennyi ideig magániskolába járt" (van Zanten 2009: 8). Az ilyen gyerekek magas arányát többek között az magyarázza, hogy miután a francia iskolarendszerben 1963 óta érvényesül a szabad iskolaválasztást korlátozó körzetesítés elve, az egyházi iskola választása a szülők számára a körzethatárokból eredő kötöttségek megkerülésének egyik módja, és egyben a gyermek számára megfelelőnek tűnő iskola megválasztásának egyik eszköze. Az egyházi égisz alatt folyó oktatás választását nagyban megkönnyíti, hogy a világnézeti semlegesség elvének érvényesülése miatt a franciaországi egyházi iskolák jó részében is tanulhatnak úgy is a diákok, hogy nem kell hittanra járniuk, illetve nem várják el tőlük a vallásos elvekkel való azonosulást. Az egyházi iskolákba íratást az is megkönnyíti, hogy az ilyen iskolák az államiaknál nagyobb önállóságot élveznek, és így nagyobb az esély arra, hogy a diákok szükségleteikre jobban tekintettel lévő, személyre szabottabb oktatásban részesülnek majd.

A két iskolarendszer közötti átlépéseken túl további tanulói mobilitást gerjeszt az, hogy ma már az egyes állami iskolák müködésmódja, légköre, programkínálata is eltérhet egymástól. Az elmúlt évtizedekben az állami iskolák kínálata is differenciálódott, különféle speciális osztályok jöttek létre. Vannak például idegen nyelvként oroszt vagy kínait tanító iskolák, illetve úgynevezett „európai osztályok”. Ezek választása jó lehetőséget kínál a körzethatárok megkerülésére. Gyakran nem az iskola programja, hanem az intézmény jó vagy rossz hírneve késztet sok szülőt, főként magasabban iskolázottakat arra, hogy hamis lakcímbejelentések révén ne a körzet iskolákba írassák gyermeküket.

A szülők iskolaválasztási stratégiái tükrében nem meglepő, hogy egy oktatásszociológus már a nyolcvanas évek elején Iskolafogyasztók címmel írt nagy sikert aratott elemzést, amelyben a szülők magatartását a hipermarketek gazdag árukínálatából választó 
vásárlókéhoz hasonlította (Ballion 1982). A közelmúltban pedig a már említett Agnès van Zanten jelentetett meg Cristian Maroy-val és egy harmadik szerzővel közösen egy könyvet, amelyben az iskolai piacok tipizálására, illetve müködésmódjuk megragadására tettek kísérletet (Felouzis-Maroy-van Zanten 2013).

Ha már a stratégiáknál tartunk, látni kell azt is, hogy nemcsak egyes szülők választanak gyermekeiknek iskolát, hanem a korábbinál decentralizáltabb franciaországi oktatásirányítási közegben az iskolák szintjén is megfigyelhető a stratégiaalkotás. Így például az a törekvés, hogy különféle speciális osztályok indításával vagy egyéb megoldásokkal küzdjenek az ellen, hogy gettósodjon, azaz jórészt a képzetlenebb, szegényebb szülőktől származó gyerekek gyưjtőhelyévé váljon egy iskola. Más oktatási intézmények vezetői pedig arra törekszenek, hogy továbbra is elit környezetből származó, motivált, könnyen tanítható, jó továbbtanulási esélyekkel rendelkező gyerekek kerüljenek hozzájuk. Mindez annak kedvez, hogy az egyes iskolák a területi oktatásirányítási szervek törekvéseit keresztező, semlegesítő kvázipiaci stratégiákat érvényesítsenek. E stratégiák érvényre jutása következtében bonyolult kölcsönös függőségi kapcsolatok alakulnak ki az egyes térségek, városrészek oktatási intézményei között. A tekintélyes Revue Française de Pédagogie című folyóirat 2006-ban tematikus blokkot szentelt az iskolák közötti kölcsönös függőségi viszonyok elemzésének, többek között olyan esettanulmányok segítségével, amelyek a Reguleducnetwork-kutatásba bevont öt európai ország egy-egy térségében készültek. ${ }^{10}$ Terjedelmi okok miatt meg kell elégednem azzal, hogy az észak-franciaországi Lille város iskolái közötti kölcsönös függőségeket elemző tanulmányból emeljek ki egy részt: „A z 1980-as évek közepétől alakult ki verseny helyi szinten az alsó középiskolák között [...]. A felújítás alatt álló városközpontban elhelyezkedő Renoir alsó középiskola 1989ben hivatalos engedély nélkül hozott létre európai osztályokat. Ennek az új tagozatnak a bevezetése azt célozta, hogy versenyre keljenek azzal a két tannyelvủ tagozattal, amelyet már jó ideje működtetnek a szintén központi fekvésű, Racine-ról elnevezett alsó középiskolában, amely egyébként mindig is a legnagyobb presztízsűnek számító lille-i líceum alsó tagozataként müködött." (Barthon-Monfroy 2006: 36).

Sok ország hasonló tendenciáit figyelembe véve vonta le Christian Maroy azt a következtetést, hogy az iskolarendszerben érvényesülő folyamatok alakulását nagymértékben befolyásolják piaci, illetve kvázipiaci mechanizmusok, amelyek az oktatás posztbürokratikus szabályozásának egy másik, a fentebb már érintett értékelési folyamatoktól eltérő megnyilvánulási formájának tekinthetők.

A korábban már többször említett Reguleducnetwork-kutatás összefoglaló tanulmányában Maroy a posztbürokratikus irányítás típusainak megragadására törekedve egyfelől az államnak az oktatási rendszer müködésének értékelésére irányuló tevékenységeit, másfelől az oktatás terén érvényre jutó kvázipiaci jelenségeket, az iskolák között kibontakozó, a tanulók megszerzésére, megtartására irányuló verseny dimenzióját helyezte elötérbe.

Jómagam arra hajlok, hogy az oktatási folyamatokba bekapcsolódó aktorok számát megsokszorozó, és megannyi sajátos helyi mintázat kialakulásának kedvező oktatásügyi decentralizációs folyamatokat is úgy tartsam számon, mint amelyek egyfelől megkérdő-

10 A francia folyóirat hasábjain megjelent, a szintén az iskolák közötti kölcsönös kapcsolatokat, illetve versenyt elemző budapesti esettanulmányunk tartalmához sokban hasonló, magyar nyelvü elemzéseket is közöltek a magyar kutatócsoport tagjai (Bajomi et al. 2006a, 2006b). 
jelezik a hagyományos bürokratikus irányításmódot, másfelől pedig posztbürokratikus működésmódok megjelenését eredményezik. A kiemelt körzetek működéséről mondottak alapján a posztbürokratikus irányításmód egyik megnyilvánulási formájának tekintem azokat a nagyszabású állami programokat is, amelyek valamilyen probléma megoldása érdekében kívánják előmozdítani az oktatási intézményeken belüli szereplők közötti kooperációt, és amelyek ösztönzően hatnak a különböző humánszolgáltató intézmények, illetve civil szervezetek közötti együttműködés bevett gyakorlattá válására. Ilyen müködésmódok érvényre jutását segítették elő például a leromlott városnegyedek életviszonyait javítani hivatott nagyszabású franciaországi várospolitikai programok, amelyekbe oktatási intézmények is bekapcsolódhattak.

Szeretném arra is felhívni a figyelmet, hogy az oktatásirányítás terén a posztbürokratikus irányításmód intézményesüléseként értékelhető változásokhoz nagyon hasonló változások figyelhetők meg a vállalatok világában. A Boltanski-Chiapello szerzőpáros által jegyzett A kapitalizmus új szelleme címü impozáns munka (Bajomi 2006b) azt érzékelteti gazdag empirikus anyagra támaszkodva, hogy míg a huszadik század első felében a vállalatirányítás terén meghatározó szerepet játszott a hierarchikus függésen alapuló, az egyének feladatkörét erősen behatároló bürokratikus irányításmód, az elmúlt évtizedekben mindinkább előtérbe került a projektlogika. Ez kedvez annak, hogy kiegyenlítettebb kapcsolatokon alapuló, rugalmas együttműködés alakuljon ki különféle egységekhez tartozó, különböző tudásokkal, információkkal rendelkező munkavállalók között. Ez egyben azt is feltételezi, hogy az együttmüködésbe bevontak odaadóan, innovatív módon vesznek részt a közös feladatok megoldásában.

$\mathrm{A} z$ imént amellett próbáltam érvelni, hogy Christian Maroy-tól eltérően nemcsak az értékelést előtérbe állító, illetve piaci, kvázipiaci mechanizmusoknak teret engedő irányítási, illetve szabályozási formákat érdemes számon tartani a posztbürokratikus szabályozás megnyilvánulási formáiként, hanem az oktatás sok szereplőjét mozgósító projektlogikájú szerveződéseket is, amelyek a hierarchikus dimenziók mellett a horizontális együttmüködéseknek is széles teret adhatnak.

Abban viszont egyetértek Maroy-val, hogy az egyes vizsgált országokban - legalábbis a közös kutatás öt államában - sosem tiszta modellekkel találkozhatunk, hanem inkább különféle modellek egymásra rakódásával. E kérdéskör kapcsán egy tanulmányában belga szociológus kollégám idézett egy mondatot, amely eredetileg a Regleducnetworkvizsgálódások egyik részkutatásának általam és egy portugál kollégám, Joao Barroso által jegyzett összefoglaló tanulmányában szerepelt: „Megfigyelhető a modellek hibridizációja, ami »a különböző logikák, gyakorlatok és diskurzusok egymásra rakódásából következik, és amiből még inkább következik ezek ellentmondásos és elegyes jellege« (Barroso et Bajomi 2002: 21)." (Maroy 2008: 46.)

Figyelembe véve a hibridizációs jelenségeket, joggal fogalmazható meg írásom végén az a kérdés, hogy a modern oktatási rendszerek működésében tetten érhető különböző szabályozási logikák, irányításmódok közül melyiknek van meghatározó szerepe. Nehéz lenne állást foglalni ebben a kérdésben, de fontosnak tartom megemlíteni, hogy a kétezres évek első évtizedében napvilágot látott egy olyan tanulmány, amelynek szerzője azt próbálja bizonyítani, hogy az oktatási folyamatok szabályozása terén Franciaországban továbbra is meghatározó a bürokratikus irányításmód szerepe. Absztraktjában így fogalmaz a szerző, aki egy francia megyei szintű oktatásirányítási egység tanár- és diáklétszám-tervezési, illetve erőforrás-allokálási folyamatainak tanulmányo- 
zása alapján jutott a fenti a következtetésre: „Etnografikus vizsgálódásokra támaszkodó tanulmányomnak két célja van. Egyfelől rá szeretnék mutatni arra, hogy milyen korlátai vannak a bürokratikus logikák térvesztéséről szóló tételnek, és egyben bizonyítani kívánom, hogy a mindennapos szakmai tevékenységek tekintetében az oktatásirányítás továbbra is alapvetően bürokratikus jellegünek tekinthető. Egyúttal azt is elemzem, hogy milyen okokra vezethető vissza a szóban forgó bürokratikus formának a tartós fennmaradása." (Laforgue 2007: 153.)

\section{IRODALOM}

Вајом I. (2006a) A partneri együttmüködés kérdései a nyugat-európai kiemelt oktatási körzetek gyakorlatában és idehaza. In: Вајомі I.: Konfliktusok és konszenzusképzés az oktatásban. Budapest, Új Mandátum Könyvkiadó. pp. 98-107.

Вајом I. (2006b) A kapitalizmus harmadik szelleme. Educatio, Vol. 15. No. 2. pp. $443-$ 447. epa.oszk.hu/01500/01551/00036/pdf/816.pdf [Letötve: 2019. 06. 02.]

Вајом I. (2013) Decentralizációs intézkedésekkel korrigált francia oktatásirányítási rendszer. Educatio, Vol. 22. No. 1. pp 60-72. epa.oszk.hu/01500/01551/00063/pdf/ EPA01551_educatio_2013_01_060_072.pdf [Letöltve: 2019.06. 02.]

Вајомі I. (2015) Széles körű konzultációk a francia közoktatás fejlesztéséről. Új Pedagógiai Szemle, Nos. 7-8. pp. 117-127. https://folyoiratok.ofi.hu/uj-pedagogiai-szemle/szeleskoru-konzultaciok-a-francia-kozoktatas-fejleszteserol [Letöltve: 2019. 06. 02.]

Bаjomi, I. \& Barroso, J. (2002) Systèmes éducatifs, modes de régulation et d'évaluation scolaire et politiques de lutte contre les inégalités en Angleterre, Belgique, France, Hongrie et au Portugal, synthèses des études de cas nationales (Oktatási rendszerek, szabályozási módok, oktatási értékelés, továbbá az egyenlötlenségek elleni harc Angliában, Belgiumban, Franciaországban, Magyarországon és Portugáliában). Lisszabon, Deliverable 3 Reguleducnetwork.

Bajomi I., Berényi E., Erőss G. \& Imre A. (2006a) Az autonómia fellegvárai (egy kerület és iskolái - egy európai kutatás tapasztalatai). Új Pedagógiai Szemle, Nos. 7-8. pp. 3-16. https://epa.oszk.hu/00000/00035/00105/2006-07-ta-Tobbek-Autonomia.html [Letöltve: 2019. 06. 02.]

Bajomi I., Berény E., Erőss G. \& Imre A. (2006b) Positions, logiques d'action et inégalités entre les écoles d'un arrondissement de Budapest (Pozíciók, cselekvési logikák és iskolák közötti egyenlőtlenségek Budapest egyik kerületében). Revue française de pédagogie, No. 3. (No. 156) pp. 39-50. https://www.cairn.info/revue-francaise-depedagogie-2006-3-page-6.htm. [Letöltve: 2019.06.02.]

BALLION, R. (1982) Les consommateurs d'école: stratégies éducatives des familles (Iskolafogyasztók: a családok oktatási stratégiái). Párizs, Stock.

Barthon, C. \& Monfroy, B. (2006): Une analyse systémique de la ségrégation entre collèges: l'exemple de la ville de Lille. (Az alsó középiskolák közötti szegregációelemzése rendszerelméleti megközelítésben Lille városának példája alapján). Revue française de pédagogie, No. 3. (No. 156). pp. 39-51; DOI: 10.4000/rfp.278. [Letöltve: 2019. 11. 20.]

Bidwell, C. E. (1965) The School as a Formal Organization. In: J. G. MArCH (ed.) Handbook of Organizations. Chicago, Rand-McNally. pp. 972-1022.

Boltanski, L. \& Chiapello, E. (1999) Le nouvel esprit du capitalisme (A kapitalizmus új szelleme). Gallimard, Párizs. 


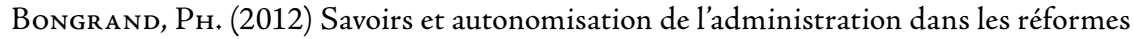
de l'Instruction publique sous Jules Ferry (1879-1883). (Tudások és az oktatásirányítás autonómmá válása Jules Ferry 1879-1883 közötti közoktatási reformjai idején). Gouvernement et action publique, No. 4. pp. 115-137. https://www.cairn.info/revuegouvernement-et-action-publique-2012-4-page-115.htm [Letöltve: 2019. 06. 02.]

Снамвon, A. \& Proux, M. (1988) Zones d'Education Prioritaires, un changement social en éducation? (Kiemelt oktatási körzetek - változás az oktatás terén)? Revue française de pédagogie, No. 83. pp. 31-38.

Condette, J.-F. (2004) Les recteurs d'académie en France de 1809 à 1940: évolution d'une fonction administrative (A tankerületi rektorok Franciaországban 1808 és 1940 között: egy közigazgatási tisztség változásai). Revue d'histoire moderne $\mathcal{E}$ contemporaine, No. 1. (No. 51/1) pp. 62-93. https://www.cairn.info/revue-d-histoire-moderne-etcontemporaine-2004-1-page-62.htm [Letöltve: 2019. 06. 02.]

Felouzis, G., Maroy C. \& van Zanten. A. (2013) Les marchés scolaires; Sociologie d'une politique publique d'éducation (Az iskolapiacok; Egy oktatásügyi közpolitika szociológiája). Párizs, PUF.

Hamon, H. (2007) La machine à dire non (A mindenre nemet mondó gépezet). Pouvoirs, No. 3. ( $\left.\mathrm{N}^{\circ} 122\right)$ pp. 61-71. https://revue-pouvoirs.fr/La-machine-a-dire-non.html [Letöltve: 2019. 06. 02.]

Hamon, H. \& Rotman, P. (1984) Tant qu'il y aura des profs (Amíg még vannak tanárok). Párizs, Le Seuil.

Karády V. (2005) A Francia Egyetem Napóleontól Vichyig. Budapest, Felsőoktatási Kutatóintézet, Új Mandátum Könyvkiadó.

LAForgue, D. (2007) L'administration scolaire française est-elle une bureaucratie? (Bürokráciának tekinthetö-e a francia oktatásirányítás?) Pyramides, No. 14. https://journals. openedition.org/pyramides/267 [Letöltve: 2019. 05. 31.]

Maroy, C. (2006) Politiques éducatives et transformations des modes de régulation institutionnels des systèmes éducatifs (Oktatáspolitikák és az oktatási rendszerek intézményes szabályozási módjainak átalakulásai). In: C. MAroy (ed.) École, régulation et marché. Une comparaison de six espaces scolaires locaux en Europe (Iskola, szabályozás és piac - hat európai helyi szintű oktatási térség összehasonlítása). Párizs, PUF. pp 33-71. https://www.cairn.info/ecole-regulation-et-marche--9782130556480-page-33.htm [Letöltve: 2019. 10. 28.]

Maroy, C. (2008) Vers une régulation post-bureaucratique des systèmes d'enseignement en Europe? (A posztbürokratikus oktatásirányítás irányába tartanak az európai országok?) Sociologie et sociétés, Vol. 40. No 1. pp. 31-55. https://www.erudit.org/fr/revues/ socsoc/2008-v40-n1-socsoc2509/019471ar/ [Letöltve: 2019. 08. 10.]

Moisan, C. \& Simon, J. (1997) Les déterminants de la réussite scolaire en ZEP (Az iskolai sikerességet meghatározó tényezök a kiemelt körzetekben). Párizs, INRP.

Pons, X. (2012) De nouvelles connaissances pour une nouvelle gouvernance par les résultats ? L'exemple de l'éducation en France et de trois outils d'évaluation. (Egy új kormányzási módot elősegíteni hivatott új ismeretek? A franciaországi oktatás és három értékelési eszköz példáján.) Recherches sociologiques et antropologiques, No. 2. pp. 15-34. http://journals.openedition.org/rsa/784; DOI : 10.4000/rsa.784 [Letöltve: 2019. 06. 02.]

Poucet, B. (2008) Les successions rectorales dans l'académie d'Amiens depuis 1808 (Az 1808 óta egymást váltó amiens-i rektorok). Carrefours de l'éducation, No. 2. pp. 25-40. https://www.cairn.info/revue-carrefours-de-l-education.htm [Letöltve: 2019. 06. 02.] 
Projet d'établissement (2014) Collège George Sand, Académie de Reims (2015-2018) (A Reimsi tankerület George Sand alsó középiskolájának intézményfejlesztési terve). sepia.ac-reims.fr/clg-george-sand/-joomla-/images/stories/documents/PROJET_ ETABLISSEMENT_CLG_GEORGE_SAND_2015_2018.pdf [Letöltve: 2019. 08. 12.]

Tourret, L. (2018) Les évaluations nationales des élèves n'ont plus aucun sens (Az országos szintű tanulói teljesítményértékeléseknek ma már nincs semmi értelme). Slate, 2018. okt. 16. www.slate.fr/story/168617/ecole-jean-michel-blanquer-ministere-educationnationale-evaluation-scientifique-independante [Letöltve: 2019. 06. 02.]

van Zanten, A. (2008) Régulation et rôle de la connaissance dans le champ éducatif en France. Du monopole à l'externalisation de l'expertise? (Szabályozás és az ismeretek szerepe a francia oktatási mezőben. A monopóliumtól a szakértői tevékenységek kiszervezéséig?) Sociologie et sociétés, No. 1. pp. 69-92. https://www.erudit.org/fr/revues/ socsoc/2008-v40-n1-socsoc2509/019473ar.pdf [Letöltve: 2019. 06. 02.]

van Zanten, A. (2009) Choisir son école (Iskolaválasztás). Párizs, PUF.

Verneuil, Y. ( 2016) De l'«omnipotence des bureaux» à la représentation du personnel : les organes de décision concernant l'avancement et les promotions dans l'enseignement secondaire entre 1808 et 1940 („A hivatal mindenhatóságától” a tanszemélyzet képviseletéig: az előmenetellel és az előléptetésekkel foglalkozó döntéshozó szervek a középfokú oktatásban 1808 és 1940 között). Histoire de l'éducation, No. 1. (№ 145) pp. 45-78. https://www.cairn.info/revue-histoire-de-l-education-2016-1-page-45.htm [Letöltve: 2019. 10. 28.]

Z $\mathrm{AY}$, J. (é. n.) Devant le Conseil supérieur de l'Instruction publique (A Közoktatási Főtanács előtt). https://www.samuelhuet.com/paid/43-melanges/753-j-zay-csipublique.html_ [Letöltve: 2019. 06. 02.]

A cikk a Creative Commons Attribution 4.0 International License (https://creativecommons.org/licenses/ by/4.0/) feltételei szerint publikált Open Access közlemény, melynek szellemében a cikk bármilyen médiumban szabadon felhasználható, megosztható és újraközölhető, feltéve, hogy az eredeti szerző és a közlés helye, illetve a CC License linkje és az esetlegesen végrehajtott módosítások feltüntetésre kerülnek. (SID_1) 